\title{
ON THE HOUSING OF THE WORKING CLASSES IN HACKNEY.
}

By J. KING WARRY, M.D.

Medical Officer of Health of the Metropolitan Borough of Hackney.

THE provision of "proper" house accommodation for all classes of the community is essential for its healthy growth, and by the term "proper" is meant not only a dwelling which is strueturally sanitary, with healthy surroundings, but also an absence of such overcrowding among its inmates as would eause danger or injury to their health.

The evils of insanitary dwellings and surroundings, and the importance of removing them, have long been recognised by the public. Much progress in the improvement of insanitary conditions has been made in Hackney during the last eight or nine years under the provisions of the Public Health (London) Act, 1891, and the Housing of the Working Classes Act, 1890, particulars of which may be found in my Annual Reports for those years; but the importance of controlling overcrowding has not received all the attention which we shall see it deserves when we consider some of its results. Something, however, has been done in Hackney in registering a certain number of tenement dwellings under the byelaws for houses let in lodgings, and causing these to be periodically inspected.

It is well known that overcrowding has a general prejudicial effect upon the constitution, rendering it more vulnerable to the attacks of disease. It has also been proved by Dr. Shirley Murphy, Medical Officer of Health of the London County Council, in his Report for the year 1898, that the mortality from phthisis rises and falls with the degree of overerowding. This is also the case with the general death-rate. We know, besides, that the more densely populated any area, the more danger there is of infectious disease spreading, with more fatal effect. That overcrowding tends also to lower the standard of morals, public and domestic, must not be forgotten. These results surely justify the most strenuous efforts and sacrifices being made to diminish overerowding.

The reason why so much progress has not been made in the Metropolis in dealing with overcrowding lies in its inherent diffculties. It is not so easily ascertained as structural sanitary defects; its full extent is not to be measured without a-house-to house visitation; and the causes leading up to it are quite different 
and of a social character. The acquisition of "proper" housing accommodation is more or less a question of means. To the skilled artisan and better classes this accommodation is attainable without much difficulty, but as we approach the lower classes the difficulties increase until, for the most helpless class, housing has to be provided by the Poor Law in the form of parochial relief.

The past efforts to house the London poor have mainly been in the direction of clearing insanitary areas, and the erection in their place of comfortable and sanitary dwellings, with improved surroundings. As an attempt to reduce overcrowding, except the overcrowding of houses on a given site, this method cannot be considered a success because :

(a) The accommodation has invariably been less than suffcient to house those displaced;

(b) The closure and demolition of insanitary dwellings have always preceded the housing of displaced dwellers, with the immediate result of increasing the overcrowding of neighbouring houses or those in adjacent districts;

(c) Owing to the conditions under which the new dwellings have been built, their rental is too high to be paid by the majority of those poor tenants displaced; and

(d) The sehemes have been too local, and their execution has extended over too long a period, to have had any appreciable effect in solving the housing problem.

In order to ascertain the amount of overerowding in any district, a minimum standard of house space must first of all be decided upon below which danger to health may be anticipated. It has been ascertained by experiment that, in order to keep the atmosphere of any inhabited room tolerably free from the products of respiration, etc., and ventilate without creating any excessive draughts, it is necessary to allow a space of at least 750 cubic feet per adult. In practice such a standard could never be generally applied; therefore a standard of 400 cubic feet, applied to rooms used for both living and sleeping, and 300 eubie feet to rooms used for sleeping alone, has been adopted by the Local Government Board for " houses let in lodgings," not because from a health point of view this standard is regarded as sufficient, but because, in view of wages, rent, etc., in London, it is all that can now be enforced. As this is the class of dwellings usually oceupied by the working classes, I have taken this standard as a basis for my remarks on overerowding in the Borough of Hackney. 
From numerous inspections and measurements of the cubic space of houses registered in Hackney during the years 1898-1900, under the Bye-Laws for Houses let in Lodgings, I have found that even if no deduction of the air space. is made for furniture or the bodies of the occupants, an average of two adults per room used for sleeping and living is the utmost which can be allowed without overcrowding coming in, with all its evil consequences. Of 44.9 houses let in lodgings and registered in the Borough, I find that 428 allowed two persons per room without overerowding, but three persons per room overerowded them; and in 21 houses only could three persons per room be housed without overcrowding on the low standard taken. In the 449 houses above mentioned there were 1,003 tenements, and of these 88 were overerowded, which is equal to 8.2 per cent. of the total. After a careful consideration of the cireumstances, I am of opinion that any excess of two persons per room in tenement houses means overcrowding, the evil effects of which become more pronounced as the inmates per room inerease beyond this number. How tar the standard I have taken is exceeded in Hackney at the present time it is impossible to say without taking a census of the Borough, but an approximation may be arrived at by an examination of the census of 1891 and 1896.

It will be seen from the following table, copied from the RegistrarGeneral's Census Report of 1891, that out of a total of 4,715 oneroomed tenements, there were 1,210 with three and more occupants to each tenement, giving an average of 3.4 persons per room; of 6,722 two-roomed tenements, there were 1,451 having five occupants and over to each; of 8,078 three-roomed tenements, there were 964 each having seven occupants and over; and of 6,401 four-roorned tenements, there were 473 each having eight oceupants and over, the general average for the 4,098 tenements being three persons per room.

Total Tenements, and Tenements with less than Five Roovs, Distinguishing those Occupied by Various Numbers of Persons in the Santiary Area of the Rugistration Division (Census 1891).

\begin{tabular}{|c|c|c|c|c|c|c|c|c|c|c|c|c|c|c|}
\hline \multirow{2}{*}{ Sanitary Area. } & \multirow{2}{*}{ 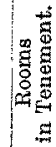 } & \multirow{2}{*}{ 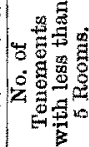 } & \multicolumn{12}{|c|}{ NOMBEE OF OCCUPANTS OF THAEMENTS. } \\
\hline & & & 1 & 2 & 3 & 4 & 5 & 6 & 7 & 8 & 9 & 10 & 11 & $\begin{array}{l}12+8 \\
\text { more }\end{array}$ \\
\hline \multirow{4}{*}{$\begin{array}{l}\text { Hacknoy (total } \\
\text { ten e me n ts, } \\
48,130) \text {, }\end{array}$} & $i$ & 4,715 & 2,113 & 1,392 & 698 & 348 & 121 & 32 & 6 & 3 & 1 & $\cdots$ & 1 & .. \\
\hline & 2 & 6,722 & 727 & 1,966 & 1,496 & 1,082 & 713 & 431 & 189 & 83 & 28 & 6 & $I$ & . \\
\hline & 3 & 8,078 & 290 & 1,712 & 1,708 & 1,430 & 1,167 & 801 & 497 & 277 & 185 & 41 & 11 & 3 \\
\hline & 4 & 6,501 & 120 & 730 & 1,012 & 1,140 & 996 & 908 & 654 & 480 & 272 & 129 & 54 & 18 \\
\hline
\end{tabular}


These figures refer to the registration district, which included Stoke Newington, but a close approximation to the number for Hackney alone may be made by reducing the total in the proportion that the houses of the former bear to the latter district. This gives the number 22,398 tenements of one to four rooms at the census 1891 in Hackney alone, which I believe to be rather an under-estimate. As stated above, to obtain the exact number of tenements of Hackney at the present time, a house-to-house inquiry would be necessary, and it is doubtful if even then the exact number of occupants would be known. In the absence of this, we may assume that the rate of increase of tenements in the district during the intercensal period 1891-1896, which was 1,034 per year, has been maintained up to the present, and that the proportion of overcrowding existing in 1891 has not diminished since that date. I am of opinion that these assumptions are fully justified, and in reality fail to represent wholly the congested state of the tenements occupied by the working classes.

The total number of tenement houses in Hackney at the census 1896 was 46,611 , which, if the above rate has been maintained, would have increased at the present time to 51,521 ; and if the proportion of overerowding remained the same, would give at the present time in round numbers 4,500 tenements in Hackney, or 8.7 per cent. of the total, with more than two persons oceupying each room-that is to say, overerowded. It will be seen that this percentage agrees elosely with the actual percentage of tenements found overerowded during the inspection of houses let in lodgings, therefore $I$ am inclined to believe that 8 per cent. may be regarded as a fairly reliable estimate of the overcrowding of tenement dwellings in the Borough of Hackney at the present time.

The causes of social phenomena are almost always complex, and defy any very exact analysis, but proximate causes are generally more or less apparent, and in considering those of overerowding, the following, I am of opinion, have exercised the largest influence :

(a) Inadequate Building of Workmen's Dwellings. - From the following table it will be seen that the inhabited houses at the census of 1881 averaged $6 \cdot 1$ occupants per house; at the census of 1891 this average had been raised to 7.0 per house; and at the census of 1896 to 7.3 per house. I estimate the average at April, 1900 , to be $7 \cdot 4$ per house. 
Population and Hocses in Hackney at Censuses 1881, 1891, 1896 (1900 ESTIMATHO).

\begin{tabular}{|c|c|c|c|}
\hline Census Years. & Population. & $\begin{array}{c}\text { Inhabited } \\
\text { Houses. }\end{array}$ & $\begin{array}{c}\text { Average Inmates } \\
\text { per House. }\end{array}$ \\
\hline 1881 & 163,681 & 23,934 & $6 \cdot 8$ \\
1891 & 198,606 & 28,422 & $7 \cdot 0$ \\
1896 & 213,044 & 29,429 & $7 \times 2$ \\
1900 (estimated) & 224,592 & 30,146 & $7 \cdot 4$ \\
\hline
\end{tabular}

Further, if we take the decennium 1881-1891 and compare the number of houses erected with the increase of population during that period, we shall find that 4,488 new houses had to provide accommodation for 34,925 persons, allowing $7 \cdot 7$ persons to each house; and if we make the same comparison for the quinquennium 1891-1896, we shall find that 997 houses erected during this period had to provide accommodation for 14,438 persons, giving 14.4 persons to each house; and from the census of 1896 to April, 1900,817 have been erected, which for an estimated increase of 11,548 population gives 14 persons to each house. So that from 1881 to 1900, for a period of 19 years, at least, the growth of popalation in Hackney has increased at a greater rate than its housing accommodation, leading to the increase of overcrowding with its evils, and there is every reason to believe that this disproportion is continuing at the present time. But it may be objected that in the census the large blocks of workmen's dwellings capable of accommodating large numbers are each counted in the census as one house, and by including such in the above calculation, my results are not accurate; but on inquiring into this matter, $I$ am of opinion that this view of the case may be neglected, as the relations I have established would not be materially disturbed by following the method of the Registrar-General.

Other evidence pointing in the same direction may be seen in the following table, which shows the number of unoccupied houses in Hackney at the censuses 1881, 1891, 1896, and at Michaelmas, 1900 .

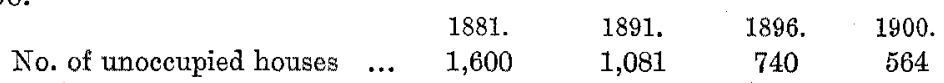

These figures show at least an increasing demand for housing accommodation, and strengthen the above conclusions.

(b) Increased Cost of Building Materials and Labour, leading to Increased Value of Houses, with corresponding Rise in Rent.-The following table shows the average prices of the chief materials used in building, together with the rate of wages of the chief workmen and labourers employed in the years 1880, 1890, and 1900: 
Average Prices of Materials and Labour during the Years 1880, 1890, AND 1900.*

\begin{tabular}{|c|c|c|c|c|c|}
\hline & & 1880. & 1890. & 1900. & $\begin{array}{l}\text { Average } \\
\text { Increase. } \\
\text { Per Cent. }\end{array}$ \\
\hline \multicolumn{2}{|c|}{ Materials. } & \multirow{8}{*}{$\begin{array}{l}27 / \text { - per } 1,000 \\
£ 10 \text { St. } \text { Petersg. } \\
\text { Standard } \\
£ 13 \text { per ton } \\
£ 5 \text { per ton } \\
4 / 6 \text { feet cube } \\
10 /- \text { per yard } \\
35 / \text { - per ton }\end{array}$} & \multirow{3}{*}{$\begin{array}{l}30 /- \\
£ 10\end{array}$} & \multirow[b]{2}{*}{$37 / 6$} & \multirow[b]{2}{*}{39} \\
\hline Bricks & Average stocks & & & & \\
\hline Timber & $\begin{array}{c}\text { Average } 3 \text { by } \\
9 \text { Yel. }\end{array}$ & & & $£ 13$ & 30 \\
\hline \multirow{5}{*}{$\begin{array}{l}\text { Lead ... } \\
\text { Iron ... } \\
\text { Stone ... } \\
\text { Lime ... } \\
\text { Cement }\end{array}$} & Sheets average & & \multirow{5}{*}{$\begin{array}{c}£ 12 \& £ 13 \\
£ 5 \\
4 / 6 \\
10 /- \\
35 /-\end{array}$} & 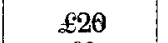 & 54 \\
\hline & Rolled joists ... & & & $£ 9$ & 80 \\
\hline & $\begin{array}{lll}\text { York } & \ldots & \ldots\end{array}$ & & & $5 / 6$ to $6 /-$ & 27 \\
\hline & Grey and Chalk & & & $12 / 6 \& 13 / 6$ & 30 \\
\hline & Portland $\quad \ldots$ & & & $42 /-$ & 20 \\
\hline \multirow{8}{*}{$\begin{array}{lr} & \text { LAI } \\
\text { Bricklayer ... } \\
\text { Carpenter } & . . \\
\text { Plasterer } & \ldots \\
\text { Plumber } & \ldots \\
\text { Painter } & \ldots \\
\text { General } & \text { la- } \\
\text { bourer } & \ldots\end{array}$} & BOUR. & \multirow{6}{*}{$\begin{array}{c}9 \mathrm{~d} . \\
9 \mathrm{~d} . \\
9 \mathrm{~d} . \\
10 \mathrm{~d} . \\
7 \frac{1}{2} \mathrm{~d} . \$ 8 \mathrm{~d} .\end{array}$} & \multirow{7}{*}{$\begin{array}{c}\text { 9d. } \\
\text { 9d. } \\
\text { 9d. } \\
10 \mathrm{~d} . \\
7 \frac{1}{2} \& \mathrm{~d} . \\
6 \mathrm{~d} .\end{array}$} & Average... & 40 \\
\hline & Rate per hour & & & $10 \frac{1}{2} \mathrm{~d}$ & 16 \\
\hline & , & & & $10 \frac{1}{2} d$ & 16 \\
\hline & $"$ & & & $10 \frac{1}{2} \mathrm{~d}$ & 16 \\
\hline & $"$ & & & $11 \frac{1}{2} d$. & 16 \\
\hline & $"$ & & & $8 \frac{1}{2} \mathrm{~d}$ & 14 \\
\hline & \multirow[t]{2}{*}{ 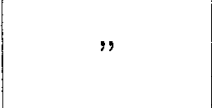 } & \multirow[t]{2}{*}{$5 \frac{1}{2} \mathrm{~d} . \& 6 \mathrm{~d}$} & & $7 \frac{1}{2} \mathrm{~d}$ & 30 \\
\hline & & & & Average... & 18 \\
\hline
\end{tabular}

It will be seen at a glance that the cost of labour and material has largely increased during the last twenty years, the average increase being shown in the table. It is obvious that this must have contributed, by its tendency to raise rents, to the increase of overcrowding.

(c) Increase in House-Rent in Working-Class Dwellings. - In the natural course of events it will only be expected that as land becomes more limited and valuable in any district, the housing accommodation will increase in value pari passu, causing a corresponding rise in rentals. In Hackney of late years there appears to have been an exceptional rise in the rentals of certain classes of dwellings occupied by the working classes.

Taking a row of 14 houses in Windsor Road, and another of 28 in Prince Edward Road, Hackney Wick, I find that in 1894 these were let at 6s. per week; in 1896 the rent was 6s. 6d. to 7s.; in 1898 had increased to $9 \mathrm{~s}$. per week, and at the present time one or two are let at 10s. per week. In 1894 the owner of one house in Windsor Road had a difficulty in letting it at $4 \mathrm{~s}$. 6d. per week, but he is now receiving $8 \mathrm{~s}$. per week for it. A shop in Windsor Road was let at 12s. per week prior to April, 1898, but since that date the rent has been raised to $16 \mathrm{~s}$. per week.

* I am indebted for these prices to Mr. W. M. Dabbs, of Upper Clapton. 
These instances show a rise of over 33 per cent. in the cost of mere housing anongst the working classes. If this be characteristic of all the working-elass dwellings in Hackney, it helps to lessen the wonder that overerowding should exist in the proportions it appears to. Perhaps an explanation of the cause of these great increases in rental may be found in the fact that the above property has changed hands four times in the last five years.

(d) Investments in House Property.-OOf late years there has been a great demand for safe investments for money. The bank interest for deposits has been low, and it has been found that house property in certain localities is one of the safest investments, and will bring in a profit of from 5 to 10 per cent. The result has been a considerable amount of speculation in house property, with a gradual rise in value and rents. The case quoted above of the change of ownership four times in five years is an example of the process outlined.

(e) Sanitary Repairs.-This may appear to have a very small influence, but I am constantly hearing of the rent of small properties being raised after the service of notice by the inspector for any necessary repairs. Of course, this is not general, but is only practised by certain holders of property.

(f) Clearance Schemes. - Within the last ten years a large amount of house property has been demolished in neighbouring parishes under Parts I. and II. of the Housing of the Working Classes Act.

The following table gives particulars of such improvement schemes carried out in the neighbouring districts:

Particulats of Somemgs under Parts I. and II. of the Housing of the

Working Claassres act undertaken by the London County Council, Vestries and District Boards, in the Distritots adjoining Hackney.

\begin{tabular}{|c|c|c|c|c|c|}
\hline Name of Area. & $\begin{array}{l}\text { Date of } \\
\text { Pepresen- } \\
\text { tation. }\end{array}$ & $\begin{array}{l}\text { Part of Act } \\
\text { under which } \\
\text { Pepre- } \\
\text { sentation } \\
\text { made: }\end{array}$ & $\begin{array}{c}\text { No. of } \\
\text { Persons } \\
\text { displaced. }\end{array}$ & $\begin{array}{c}\text { No. of } \\
(\alpha) \text { acco } \\
\text { or }(b) \text { al } \\
\text { accom } \\
\text { on }\end{array}$ & $\begin{array}{l}\text { Persons } \\
\text { monodated } \\
\text { bont to be } \\
\text { modated } \\
\text { Area. }\end{array}$ \\
\hline \multirow[t]{2}{*}{\begin{tabular}{lccc}
$\begin{array}{l}\text { Boundary } \\
\text { Green }\end{array}$ & \multicolumn{3}{c}{ Street, Bethnal } \\
Churchway, & St. & Pancras & $\ldots$ \\
Poplar & $\ldots$ & $\ldots$ & $\ldots$ \\
Poplar & $\ldots$ & $\ldots$ & $\ldots$ \\
Norfolk Square, & $\ldots$ \\
Moirlington.... Palace, & Shorediteh ...
\end{tabular}} & \multirow[t]{2}{*}{$\begin{array}{c}1890 \\
\ldots \\
1389 \\
1893.94 \\
1889 \\
1890\end{array}$} & $\begin{array}{l}\text { Part I. } \\
\text { Part I. } \\
\text { Part I. } \\
\text { Part II. } \\
\text { Part II. } \\
\text { Part II. }\end{array}$ & $\begin{array}{r}5,719 \\
1,095 \\
269 \\
261 \\
214 \\
538\end{array}$ & $\begin{array}{c}(a) \\
(b) \\
(b) \\
(a) \\
(a) \stackrel{400}{4}\end{array}$ & $\begin{array}{l}4,600 \\
832 \\
269 \\
630 \\
192 \\
(b) 72\end{array}$ \\
\hline & & Totals ... & 8,091 & $\left\{\begin{array}{l}(a) \\
(b)\end{array}\right.$ & $\begin{array}{r}5,192 \\
973\end{array}$ \\
\hline
\end{tabular}


This has necessarily led the occupants of these dwellings to seek housing accommodation elsewhere, which I have reason to believe many obtained in Hackney. It is necessarily a matter of speculation to what extent demolition under these schemes aggravated the housing tension of Hackney, but it is not insignificant on this account.

Mr. Charles Booth, in his monumental work on the "Life and Labour of the People (East London)," has divided the population into the following classes :

(a) The lowest class of occasional labourers, loafers, and semi-criminals.

(b) Casual earners-" very poor."

(c) Intermittent earnings $\}$ together- " the poor."

(e) Regular standard earnings-above the line of poverty.

(f) Higher class labour.

(g) Lower middle class.

(h) Upper middle class.

Mr. Booth applies the term "poor" to those who "have a sufficiently regular though bare income, such as 18s. to 21s. per week for a moderate family, and "very poor" to "those who from any cause fall much below this standard." This was written in 1889 , but I am inclined at the present time to extend the term "poor" to include those receiving, say, from 20s. to 25s. per week if a family is dependent upon this income. My reason for this extension lies in the fact of the rise in house-rent, and in the prices of other necessaries of life, since the date quoted.

In Mr. Booth's inquiries the above classes were found to exist in Hackney in the proportions of the annexed table, the population having been estimated at 186,000 persons. This table gives an analysis of 140,864 persons, the difference between this and the former number being the persons unscheduled and in institutions.

In these proportions the different classes existed in 1889, when the population was about 186,000 ; since that date, although the population has increased to about 227,000 , no social events have occurred to warrant us in assuming that the relative proportions of these classes have altered, especially in the direction of ameliorating the lot of classes A, B, C, D. On the contrary, I am of opinion that the proportions of these classes have not only been maintained, but in all probability have been increased at the expense of the better conditioned classes. My reasons for thinking this are: (1) Since 1889 there has been an increase in the cost of housing 
accommodation, and in the price of other necessaries of life; (2) although there has been a rise in remuneration of labour, this has been chiefly confined to skilled labour, and hardly touches the classes A, B, C, D. However, assuming the proportions of the different classes are the same at the present time, their numbers would be as follows :

\begin{tabular}{|c|c|c|c|}
\hline Classes. & $\begin{array}{c}\text { No. of } \\
\text { Persons, } \\
\text { Year } 1898 .\end{array}$ & Percentage. & $\begin{array}{c}\text { No. of Persons, } \\
\text { Year } 1901 .\end{array}$ \\
\hline $\begin{array}{l}A \\
B \\
C \\
D \\
E \\
F \\
G \\
H\end{array}$ & $\begin{array}{r}1,664 \\
15,693 \\
10,758 \\
15,142 \\
52,216 \\
32,582 \\
11,084 \\
1,775\end{array}$ & $\begin{array}{r}0.9 \\
8.6 \\
5.8 \\
8.4 \\
34.3 \\
17.8 \\
6.0 \\
18.2\end{array}$ & $\left.\begin{array}{r}2,060 \\
19,424 \\
13,316 \\
18,742 \\
64,630 \\
40,329 \\
13,657 \\
2,197\end{array}\right\} 53,542$ \\
\hline $\begin{array}{l}\text { Unscheduled and } \\
\text { in institutions... }\end{array}$ & $\begin{array}{r}140,864 \\
45,136\end{array}$ & - & $\begin{array}{r}174,355 \\
52,645\end{array}$ \\
\hline Total ... ... & 186,000 & 100.0 & 227,000 \\
\hline
\end{tabular}

Here it may be interesting to compare Mr. Booth's classification with the Registrar-General's table of persons in Hackney occupying tenements of one to four rooms. While one cannot say definitely that rooms occupied by persons of the classes A, B, C, D must necessarily be overcrowded, one is justified in the assumption that these are the classes amongst whom the most overerowding will be found, for the simple reason that these people have a great struggle to obtain the necessaries of life, and the claims of healthy and decent accommodation will give way to the more pressing needs of providing food and clothing, and to other exigencies. So while we do not expect any close correspondence in point of numbers between the classes A, B, C, D of Mr. Booth and the table of the RegistrarGeneral, we feel we are travelling as it were over the same ground and dealing to a large extent with the same individuals while considering the two tables.

The Registrar-General's table shows 9,266 persons living in' 4,715 one-roomed tenements, 21,936 persons in 6,722 two-roomed tenements, 32,700 persons in 8,072 three-roomed tenements, and 32,582 persons in 6,501 four-roomed tenements, the total number of persons housed in the four classes of tenements being 96,484. 
Mr. Booth's table shows a total of 43,257 persons in his classes $A, B, C, D$, but in considering the struggles these latter have for existence, it is more than probable that we shall find them as residents of one, two, and three-roomed tenements, and these overcrowded.

On the standard earlier adopted, i.e., a maximum of two persons per room, I find amongst the Registrar-General's four classes of tenements 4,098 with a population of 23,945 persons, living in the proportion of more than two persons in each room; and it is almost certain that these are almost wholly to be found in the classes A, B, C, D, of Mr. Booth. This assumption is supported by a consideration of the circumstances of typical cases of each class given by this writer.

The above comparison has been of service, for it has enabled us to see more definitely the class of individuals amongst whom overcrowding is to be found, and to some extent its causes. With this knowledge it will be less difficult to find a remedy.

The proportion of one's income which should be devoted to rent has hitherto been estimated at about one-tenth. This, of course, is only a round figure, and is frequently deviated from in both directions without invalidating the principle. It is probably the proportion expended by the better classes, but from information acquired during the inspection of houses registered under the bye-laws for houses let in lodgings it appears that those persons who are, as it were, on the verge of overcrowding pay for their housing accommodation at the rate of about $2 \mathrm{~s}$. $6 \mathrm{~d}$. for each room per week, that is to say, their rent fluctuates between onefourth and one-sixth of their income. If these persons could obtain accommodation at a cheaper rate, no doubt they would get it, therefore $2 \mathrm{~s} .6 \mathrm{~d}$. may be talken as the maximum amount which can be paid by the poor without foreing them into a state of overerowding, even on the low standard taken above. This is important as showing that housing accommodation if provided by the local authority must be at a lower rate than this, if overcrowding is to be diminished.

As the crux of the whole matter appears to me to be the crowding together of immense numbers of the London population in an unhealthy manner, because they cannot afford more healthy (less crowded) accommodation while the cost of housing bears the present relation to their incomes, it is quite clear that the housing of the poor will not be satisfactorily accomplished unless this relation is altered and healthy housing provided within the means of the classes referred to-that is, at a cost which bears much the 
same proportion, if not less, to their total income as that amongst the better classes. As a provisional statement, I should say that accommodation should not be more than from 1s. 6d. to $2 \mathrm{~s}$. per room per week to attract "the poor classes," and dwellings for the "very poor" should not exceed 1s. to 1s. $6 \mathrm{~d}$. per week.

As to what may be done under Part III. of the Housing of the Working Classes Act, the Act provides that a local authority having adopted Part III. of the Act may in execution thereof:

1. Purchase land for the erection of dwelling-houses for the working classes.

2. May contract for the purchase or lease of any lodginghouse for the working classes already, or hereafter to be, built or provided.

3. May erect dwellings suitable for lodging-houses for the working classes.

4. May convert existing buildings into lodging-houses, and for that purpose may alter, enlarge, repair, and improve the same respectively, and fit up, furnish, and supply the same with requisite furniture, fittings, and conveniences.

5. May, by the Amending Act of 1900 , purchase land and build dwellings suitable for the working classes outside of the district.

\section{SugGestions.}

It will readily be seen from the above what are the remedies for the conditions just detailed, but to provide these remedies is not so simple a matter. It must be remembered, that unless there is some simultaneous effort of the London Boroughs to deal with this question, any local effort must, more or less, be a failure, because the overerowded of adjoining districts would move into the district to seize the opportunity of obtaining cheap and healthy dwellings, or even residents of extra-Metropolitan districts might think it profitable to move into the district for the same purpose, but if this danger is eliminated, the Borough Council might best meet the overcrowding by providing accommodation at the cheapest possible rate compatible with health.

The measures which, in my opinion, would best meet the case are:

1. 'To urge the Government to extend the period for' the repayment of loans for the purchase of lands to ninety years, and loans for building purposes to sixty years. (The Council have already petitioned in favour of this reform.) 
2. To provide in the district for the poorest part of the community (Classes $\mathrm{A}$ and $\mathrm{B}$ ) a municipal lodging-house, to be under local control, and the price of accommodation fixed at the lowest figure sufficient to cover working expenses and a contribution to the sinking fund, ete.

3. For Classes $C$ and $D$ the Borough may

(a) Purchase and convert any suitable large houses in the Borough into tenement dwellings.

(b) Purchase land in the Borough and erect suitable dwellings thereon at the cheapest possible rate.

(c) Purchase land outside the Borough (in the suburbs), and erect suitable dwellings thereon.

There are limitations to the usefulness of this last, as those needing accommodation most are those who require to live in the district to be near their work, and the cost of conveyance to and from their work, if they lived in the suburbs, would probably, with the rent, be almost equal to lodging in the Borough.

For these last special preferential terms might be arranged with railway companies for the conveyance of the bread-winners, lodged in this way, to and from their work on weekdays; and this the companies ought to grant, as the searcity of accommodation has partly been brought about by the demolition of many houses during the construction of the railways which form a network over London.

Canned Meats.-From a series of experimental observations on the canning of meats, Drs. Bischoff and Wintgen (Zeitschrift fir Hygiene und Infectionskranthheiten, xxxiv., p. 496) conclude that penetration of heat into the interior of the meat is uneven and not wholly dependent upon the size of the pieces. The condition of the meat, whether fatty or not, whether compact or fissured, is of much importance, as is also the amount of liquid in the can. The fissures are in part caused by the cooking, which converts the connective tissue to gelatin and brings about a contraction of the muscle substance. Evenness of quality, depending upon the age of the animal, the shape of the piece, and amounts of fat and connective tissue, is not easily controlled. In consequence of the high temperature necessary for complete sterilization, the meat becomes more or less stringy, according to the nature of the piece. Absolute sterility is obtained at different temperatures under varying conditions. The best results are obtained with cans containing 600 and 200 grammes by heating at $120 \cdot 5^{\circ} \mathrm{C}$. for seventy and fifty minutes respectively, the meat being tender, though somewhat stringy, and absolutely sterile.

Canned meats are not the equals of fresh meats as used in the household, but are to be preferred for use by troops in the field to that of freshly-killed animals, consumed without undergoing any process of ripening. Moreover, they possess the advantage of easy transportation and quick preparation for use as needed.-Amer. Journ. Med. Sc. 